\title{
Demokrasi dalam Bidang Pendidikan
}

\author{
Vingki Maulana Putri \\ Institut Ilmu Kesehatan Surya Mitra Husada Indonesia \\ fingkichng95@gmail.com
}

\begin{abstract}
Abstrak :
Dalam pendidikan, demokrasi ditunjukkan dengan pemusatan perhatian serta usaha pada si anak untuk tumbuh dan berkembang menurut kodratnya. Dengan demikian tampaklah bahwa demokrasi pendidikan merupakan pandangan hidup yang mengutamakan persamaan hak dan kewajiban serta perlakuan yang sama di dalam berlangsungnya proses pendidikan antara pendidik dan anak didik, serta juga dengan pengeolola pendidikan. Karena itulah demokrasi pendidikan dalam pengertian yang lebih luas, patut selalu dianalisis sehingga memberikan manfaat dalam praktek kehidupan dan dalam lingkungan pendidikan.
\end{abstract}

\section{Kata Kunci : Demokrasi, Pendidikan}

\section{Latar Belakang :}

Demokrasi pendidikan merupakan suatu pandangan yang mengutamakan persamaan kewajiban dan hak dan perlakuan oleh ketenaga pendidikan terhadap peserta didik dalam proses pendidikan. Dengan demikian, demokrasi pendidikan adalah demokrasi yang memberikan kesempatan pendidikan yang sama kepada semua orang, tanpa membedakan ras (suku), kepercayaan, warna dan status sosial. Definisi ini memberi pengertian bahwa setiap individu mempunyai hak yang sama untuk memperoleh pendidikan dan pengajaran. Masing-masing mempunyai hak otonom untuk mengekspresikan dan mengaktualkan potensi yang dimilikinya melalui pendidikan.

Demokrasi pendidikan mengutamakan kesetaraan dan persamaan. Sebab tiap warga negara berhak mendapatkan pendidikan, apalagi bagi negara Indonesia yang 
merupakan negara demokrasi.Sedangkan di negara-negara demokrasi, diharapkan sistem pendidikan pun harus demokratis. Pendidikan yang demokratis adalah pendidikan yang memberikan kesempatan yang sama kepada setiap anak untuk mendapat pendidikan di sekolah sesuai dengan kemampuannya. Dengan demikian pendidikan sangat penting bagi seluruh bangsa tak terkecuali bagi orang-orang yang kurang mampu melanjutkan ke tingkat sekolah yang lebih tinggi. Pelaksanaan demokrasi pendidikan di Indonesia pada dasarnya telah dikembangkan sedemikian rupa dengan menganut dan mengembangkan asas demokrasi dalam pendidikannya, terutama setelah diproklamirkannya kemerdekaan, hingga sekarang. Pelaksanaan tersebut telah diatur dalam perundang-undangan yang berlaku di Indonesia, seperti pada Pasal 31 UUD 1945;

a. Ayat (1): Tiap-tiap warga negara berhak mendapatkan pengajaran.

b. Ayat (2): pemerintah mengusahakan dan menyelenggarakan satu sistem pengajaran nasional, yang diatur dengan undang-undang.

\section{Kasus/Masalah:}

Bagaimana penerapan demokrasi pendidikan di Indonesia?

Situasi yang terjadi dalam dunia pendidikan di Indonesia saat ini seringkali menampilkan wajah yang cukup kontradiktif dengan gagasan demokrasi. Hal ini dapat dilihat dari berbagai macam fakta. Pertama adalah model pembelajaran yang masih kental dengan gaya bank yang tercermin melalui: guru mengajar, murid belajar; guru tahu segalanya, murid tidak tahu apa-apa; guru berpikir, murid dipikirkan; guru bicara, murid mendengarkan; guru mengatur, murid diatur; guru memilih dan memaksimalkan pilihannya, murid menuruti. Guru dilihat sebagai gudang pengetahuan yang bertujuan untuk mentransferkan ilmunya kepada peserta didik. Paradigma seperti ini menjadi penyebab utama terhambatnya proses pembentukan ruang yang partisipatif dan melanggengnya budaya pasif dalam diri para pelajar. Para pelajar sudah beranggapan bahwa guru adalah sumber segalanya, sumber kebenaran, dianggap "perfect". Model pembelajaran inilah yang dikritisi oleh seorang tokoh pendidikan yaitu Paul Freire. Freire menekankan pentingnya pendidikan yang membebaskan, tidak ada pihak yang mendominasi dan didominasi. 
Esensi pokok dari pendidikan adalah emansipatoris termasuk membebaskan para pelajar dari cara berpikir yang tradisional, yang menganggap guru adalah segalanya serta mengabaikan potensi yang ada dalam dirinya. Yang ada hanyalah partisipasi aktif dari semua pihak. Kedua adalah persoalan pengambilan keputusan dan kebijakan dalam sebuah institusi pendidikan yang tidak melibatkan semua pihak. Pemikir kelahiran Perancis, Michel Foucault menegaskan bahwa kekuasaan dalam sebuah institusi seringkali dimodifikasi melalui berbagai macam aturan dan kebijakan yang tidak memiliki alasan rasionalitas. Akibatnya, ada pihak yang kemudian dijadikan sebagai obyek pendidikan.

Pendidikan yang demokratis merupakan gagasan yang mengedepankan unsur partisipasi aktif dari semua pihak (pemerintah, pengajar dan anak didik). Kemajuan dari sebuah institusi pendidikan tidak terlepas dari peran setiap aktor-aktor tersebut. Adanya proses integrasi secara terpadu dan terus-menerus melalui pembentukan pendapat umum (opini publik) dalam mengambil suatu keputusan merupakan esensi utama dari gagasan demokrasi. Pendidikan yang demokratis merupakan pendidikan yang mengedepankan partisipasi aktif. Semua orang memiliki kebebasan yang sama untuk menyampaikan pendapat dan gagasan dalam mengaktualisasikan dirinya. Situasi pendidikan di Indonesia pada umumnya dan di NTT pada khususnya, belum menampilkan konsep demokrasi yang sesungguhnya.Kalaupun ada, jumlahnya masih sangat minim. Oleh karena itu, sudah saatnya pendidikan yang demokratis diwujudkan, agar generasi yang lahir dari sistem pendidikan di Indonesia bukanlah generasi yang pasif, melainkan aktif, generasi yang kritis, bukan krisis dan generasi yang selalu inklusif, bukan eksklusif. Pendidikan yang bertujuan memanusiakan manusia harus diterjemahkan ke dalam praktik yang demokratis, bukan otoritarian. Mewujudkan pendidikan yang demokratis pada dasarnya bukanlah sesuatu yang sulit, sepanjang kita mempunyai misi yang sama yaitu terwujudnya keadilan sosial dalam bidang pendidikan. Semua aktor dalam dunia pendidikan memiliki kedudukan yang sama, baik sebagai peserta didik, para pendidik dan juga pemerintah.

\section{Tinjauan Pustaka:}

\subsection{Pengertian Demokrasi}

Demokrasi berasal dari bahasa Yunani, dari kata "demos" dan "cratos", demos berarti rakyat dan cratos berarti pemerintah. Jadi yang dimaksud dengan 
demokrasi adalah kekuasaan yang berakar pada rakyat. Dengan demikian dalam tema politik dikatakan bahwa kedaulatan tertinggi terletak ditangan rakyat. Sedangkan menurut kamus besar bahasa Indonesia, demokrasi diartikan sebagai: "gagasan atau pandangan hidup yang mengutamakan persamaan hak dan kewajiban serta perlakuan yang sama bagi semua warga negara". Sementara moment terpenting dari demokrasi adalah kebebasan berbicara dan berkehendak (freedom of speak and press). Artinya dalam tubuh demokrasi tercermin nilai keterbukaan sistem yang menyangkut gabungan kebutuhan naluriah dan pilihan rasional masing-masing individu. Karena itu, di dalam demokrasi ruang lingkup pertukaran ide-ide menjadi semakin luas dan melibatkan semakin banyak unsur yang ada di dalam masyarakat. Namun dalam praktek demokrasi, nilai-nilai individu tersebut di atas sering disalah gunakan, seperti yang dikemukakan Hasan Langgulung bahwa kebiasaan dari segala belenggu kebendaan kerohanian yang tidak sah yang kadang-kadang dipaksakan kepada manusia, tanpa alasan yang benar pada kehidupan sehari-hari yang menyebabkan ia tidak sanggup menikamati hak-haknya yang wajar. Sehingga yang terjadi bukan demokrasi yang di idamidamkan, tetapi anti demokrasi yang menjurus pada tindakan anarkis yang menindas hak-hak kebebasan dan martabat orang lain. Oleh karena itu, prinsip demokrasi perlu dilihat secara keseluruhan, bukan hanya secara parsial prinsipprinsip demokrasi tersebut adalah:

1) kebebasan,

2) penghormatan terhadap manusia,

3) persamaan,

4) dan pembagian kekuasaan.

Kehidupan demokrasi adalah kehidupan yang menghargai potensi individu yang berbeda dan individu yang mau hidup bersama. Dengan demikian, segala jenis persamaan masyarakat yaitu menyamaratakan anggota masyarakat menuju uniformitas adalah bertentangan dengan dengan prinsip-prinsip hidup demokrasi termasuk didalamnya pengakuan terhadap hak asasi manusia merupakan inti dari kehidupan demokrasi dalam segala aspek kehidupan. Kuatnya tuntutan demokrasi dan maraknya diskursus demokrasi, tidak lain karena adanya anggapan bahwa demokrasi merupakan suatu sistem yang bisa menjamin keteraturan politik dan 
sekaligus mendorong transformasi masyarakat menuju struktur social, politik, ekonomi dan kebudayaan yang lebih ideal. Ideal dalam arti, manusiawi, egaliter dan berkeadilan. Meskipun demokrasi sesungguhnya merupakan istilah politik, namun terjemahan dan kongkritnya tidak hanya ada didalam kehidupan politik. Seluruh aspek kehidupan manusia yang berhubungan dengan masyarakat luas dan berada dalam sistem kenegaraan membutuhkan demokrasi, karena manusia sebagai hamba Allah butuh dimanusiakan dan dimanusiawikan, sedangkan demokrasi adalah ungkapan lain dari penghormatan hak-hak azasi manusia, suatu sikap hidup insani yang mencerminkan dan dimiliki dan ditegakkannya peradaban dan kebudayaan.

\subsubsection{Prinsip-Prinsip Demokrasi Pendidikan}

Apabila dihubungkan dengan pendidikan maka pengertiannya sebagai berikut: pendidikan yang demokrasi adalah pendidikan yang memberikan kesempatan yang sama kepada setiap anak (peserta didik) mencapai tingkat pendidikan sekolah yang setinggi-tinginya sesuai dengan kemampuannya.Berdasarkan definisi tersebut dapat dipahami bahwa demokrasi pendidikan merupakan suatu pandangan yang mengutamakan persamaan kewajiban dan hak dan perlakuan oleh tenaga kependidikan terhadap peserta didik dalam proses pendidikan. Dengan demikian, demokrasi pendidikan adalah demokrasi yang memberikan kesempatan pendidikan yang sama kepada semua orang, tanpa membedakan ras (suku), kepercayaan, warna dan status sosial. Definisi ini memberi pengertian bahwa setiap individu mempunyai hak yang sama untuk memperoleh pendidikan dan pengajaran. Masing-masing mempunyai hak otonom untuk mengekspresikan dan mengaktualkan potensi yang dimilikinya melalui pendidikan. Demokratisasi pendidikan juga dilakukan dengan mengikut sertakan unsur-unsur pemerintah setempat, masyarakat dan orang tua berbentuk dalam hubungan kemitraan dan menumbuhkan dukungan positif bagi pendidikan anak. Hal ini menuntut partisipasi lebih besar dari warga lembaga pendidikan dalam setiap kebijakan dan sepanjang proses pembuatan keputusan berlangsung dan semua keputusan dibuat secara kolektif dan sinergis bersama stakeholders. Pengambilan keputusan partisipatif semacam ini merupakan suatu cara untuk mengambil keputusan melalui penciptaan lingkungan yang terbuka dan demokratik. Dalam artian bahwa warga sekolah (siswa, karyawan, orang tua siswa dan tokoh masyarakat) didorong untuk terlibat secara langsung di dalam proses pengambilan keputusan maka yang bersangkutan 
akan ada "rasa memiliki" terhadap keputusan tersebut sehingga ia juga akan bertanggung jawab dan berdedikasi sepenuhnya untuk mencapai tujuan sekolah.

Dalam setiap pelaksanaan pendidikan selalu terkait dengan masalah-masalah antara lain :

a. Hak asasi setiap warga negara untuk memperoleh pendidikan.

b.Kesempatan yang sama bagi warga negara untuk memperoleh pendidikan.

c. Hak dan kesempatan atas dasar kemampuan mereka.

Berarti demokrasi pendidikan itu harus mempunyai prinsip sebagai berikut :

1. Menjungjung tinggi harkat dan martabat manusia sesuai dengan nilai-nilai luhurnya.

2. Wajib menghormati dan melindungi Hak Asasi Manusia yang bermartabat dan berbudi luhur.

3. Mengusahakan suatu pemenuhan hak setiap warga negara untukmemperoleh pendidikan dan pengajaran nasional dengan memanfaatkan kemampuan peribadinya dalam rangka mengembangkan kreasinya kearah perkembangan dan kemajuan ilmu pengetahuan dan teknologi (IPTEK) tanpa merugikan orang lain.

Dari prinsip-prinsip tersebut dapat dipahami, bahwa ide dan nilai demokrasi pendidikan itu sangat banyak dipengaruhi oleh akal pikiran, sifat jenis masyarakat dimana mereka berada. Jika hal-hal yang disebutkan ini dikaitkan dengan prinsipprinsip demokrasi pendidikan yang terdahulu, maka ada beberapa yang harus dipahami antara lain.

1. Keadilan dalam pemerintahan adalah kesempatan belajar bagi semua warga negara

2. Dalam pembentukan karakter bangsa sebagai bangsa yang baik

3. Memiliki satu ikatan yang kuat dengan cita-cita nasional

4. Dalam bidang pendidikan cita-cita demokrasi yang akan dikembangkan dengan tidak meningglakan cita-cita dan kondisi masyarakat yang ada melalui proses vertikal dan horizontal. 
Dengan demikian, prinsip-prinsip demokrasi dan pendidikan dapat diklasifikasi sebagai berikut.

\section{Adanya kesamaan hak dan kewajiban.}

2.Adanya pengakuan atas kebebasan berpendapat, bertindak, dan berinisiatif.

3.Kebijakan yang ditempuh berlandaskan pada keberagaman nilai-nilai masyarakat.

4.Lebih mengutamakan kepentingan mayoritas.

Memperhatikan prinsip di atas, dapat dikatakan bahwa pendidikan sebagai penentu keberhasilan pelaksanaan demokrasi, dan demokrasi akan memberikan keberhasilan kualitas pendidikan. Hal tersebut lebih memberikan pada makna peranan sumber daya manusia dalam menjalankan nilai-nilai kemasyarakatan. Semakin tinggi kualitas masyarakat sebagai hasil proses pendidikan, semakin besar kemungkinan masyarakat mengerti tentang penerapan sistem demokrasi pada suatu bangsa.

\section{Pembahasan :}

Pengertian demokrasi mencakup dua arti baik secara horizontal maupun secara vertikal. Dimaksudkan dengan demokrasi secara horizontal adalah bahwa setiap anak tidak ada kecualinya, mendapatkan kesempatan yang sama untuk menikmati pendidikan sekolah. Di Indonesia hal ini jelas sekali tercermin pada UUD 1945 pasal 31 ayat (1) yang berbunyi "Tiap-tiap warga negara berhak mendapatkan pengajaran". Sedangkan demokrasi secara vertikal adalah bahwa setiap anak mendapat kesempatan yang sama untuk mencapai tingkat pendidikan sekolah yang setinggi-tingginya sesuai dengan kemampuannya.

Setelah kita mengetahui arti demokrasi secara umum ada baiknya kita mengetahui arti pendidikan itu sendiri. Arti pendidikan menurut Ki Hajar Dewantara yaitu tuntunan di dalam hidup tumbuhnya anak-anak, adapun maksudnya, pendidikan yaitu menuntun segala kekuatan kodrat yang ada pada anak-anak itu, agar mereka sebagai manusia dan sebagai anggota masyarakat dapatlah mencapai kesempatan dan kebahagiaan yang setinggi-tingginya. Sedangkan menurut kamus bahasa Indonesia, Pendidikan adalah proses pengubahan sikap dan tata laku seseorang atau kelompok orang dalam usaha 
mendewasakan manusia melalui upaya pengajaran dan pelatihan, proses atau cara perbuatan mendidik.

Dari keterangan diatas dapat disimpulkan bahwa demokrasi Pendidikan adalah proses perbuatan mendidik yang mengutamakan hak dan kewajiban serta perlakuan yang sama bagi semua peserta didik.

Demokrasi pendidikan memberikan manfaat dalam prkatek kehidupan dan pendidikan dalam beberapa hal yaitu :

\section{Rasa hormat terhadap harkat sesama manusia}

Demokrasi dianggap sebagai pilar pertama untuk menjamin persaudaraan hak manusia dengan tidak memandang jenis kelamin, umur, warna kulit, agama dan bangsa. Dalam pendidikan, nilai-nilai inilah yang memandang perbedaan antara satu dengan lainnya baik hubungan antara peserta didik dengan gurunya dengan saling menghargai dan menghormati diantara mereka.

2. Setiap manusia memiliki perubahan kearah pikirannya yang sehat.

Dari acuan prinsip inilah timbul pandangan bahwa manusia itu harus didik, karena dengan mendidik manusia akan berubah dan berkembang kearah yang lebih sehat baik dan sempurna.

3. Rela berbakti untuk kepentingan dan kebaikan bersama dalam demokrasi

kita untuk mendahulukan kepentingan bersama daripada kepentingan pribadi. Kesejahteraan hanya akan dapat tercapai apabila setiap warga negara atau anggota masyarakat dapat mengembangkan tenaga atau pikirannya untuk memajukan kepentingan bersama. Kebersamaan dan kerjasama inilah pilar penyangga demokrasi yang dengan selalu menggunakan dialog dan musyawarah sebagai pendekatan sosialnya untuk mengambil keputusan supaya tercapai satu tujuan yaitu kesejahteraan dan kebahagiaan. Jelaslah bahwa pendidikan

4. Kewarganegaraan dan ketatanegaraan menjadi penting dan sesuatu yang tidak bisa diabaikan untuk diberikan kepada setiap warga negara, anak-anak atau peserta didik dan upaya mempraktekkan salah satu dari prinsip demokrasi.

\section{Kesimpulan :}


Demokrasi pendidikan merupakan suatu kebijakan yang sangat didambakan oleh masyarakat. Melalui kebijakan tersebut diharapkan peluang masyarakat untuk menikmati pendidikan menjadi semakin lebar sesuai dengan kemampuan dan kesempatan yang dimiliki. Jurang pemisah antara kelompok terdidik dan belum terdidik menjadi semakin terhapus, sehingga informasi pembangunan tidak lagi menjadi hambatan. Ungkapan pendidikan untuk semua dan semuanya untuk pendidikan diharapkan bukan sekedar wacana tetapi sudah harus merupakan komitmen pemerintah dan masyarakat untuk mewujudkannya.

Dengan adanya demokratisasi pendidikan, maka dengan sendirinya secara prinsip akan lebih memenangkan yang bersifat terbuka, sehingga setiap warga negara dalam menikmati pendidikan seharusnya tidak lagi didasarkan atas kabilah atau kelompok tertentu saja yang memiliki uang dan atau kekuasaan.

\section{Daftar pustaka :}

Dr. Saifullah Idris, M. Ag (2014). DEMOKRASI DAN FILSAFAT PENDIDIKAN

Fajar Dedi Isnanto, FKIP UMP (2019). Implementasi pendidikan demokrasi

Fathorrahman (2020). DEMOKRATISASI PENDIDIKAN DALAM PENDIDIKAN ISLAM

Ibni Wiryateja Universitas Sebelas Maret, Juli 2020. Prinsip Demokrasi

Pendidikan

Iwan_Nasti (2011). Demokrasi dalam pendidikan

Joni Rahmat Pramudia. Demokrasi dalam pendidikan

Sodik, M. A. STATUS SOSIAL EKONOMI DAN KESEHATAN.

Putri, V. M. (2021). Kewajiban Masyarakat Menerima Edukasi Kesehatan Mental. YULITA HETY SUJAYA (2016) Demokrasi dalam Dunia Pendidikan 